Avner Sidi MD, Richard F. Kaplan MD, Richard F. Davis, MD

\title{
Prolonged neuro- muscular blockade and ventilatory failure after renal transplantation and cyclosporine
}

In a retrospective one-year study, we documented respiratory failure or prolonged neuromuscular blockade in eight of 65 patients with chronic renal failure who had received either vecuronium (four of 29 patients) or atracurium (four of 36 patients) during anaesthesia for kidney transplantation. We reviewed the charts of the patients and recorded all aspects of medication and anaesthesia to try to determine whether there might be a single factor associated with this high incidence (12 per cent) of respiratory failure. Anaesthesia for all patients was induced with thiopentone, isoflurane, and $\mathrm{N}_{2} \mathrm{O}_{1} \mathrm{O}_{2}$. Tracheal intubation was facilitated with muscle relaxants in a single bolus of vecuronium, 0.07 to $0.1 \mathrm{mg} \cdot \mathrm{kg}^{-1}$, or atracurium, 0.3 to $0.5 \mathrm{mg} \cdot \mathrm{kg}^{-1}$. Additional doses were given according to neuromuscular activity, which was monitored visually by response to train-of-four and tetanic stimulation. Anaesthesia was maintained with fentanyllisoflurane and $\mathrm{N}_{2} \mathrm{O} / \mathrm{O}_{2}$. After induction of anaesthesia, each patient received methylprednisolone, cefazolin, mannitol infusion for $24 \mathrm{hr}$ beginning at the start of renal artery anastomosis, and either azathioprine $(n=57)$ or cyclosporine $(n=8)$. Relaxation was evaluated toward the end of the operation by train-of-four stimulation. Neuromuscular blockade was reversed with edrophonium $\left(0.75-1 \mathrm{mg} \cdot \mathrm{kg}^{-1}\right)$ or neostigmine $\left(0.06-0.08 \mathrm{mg} \cdot \mathrm{kg}^{-1}\right)$. The eight patients with prolonged neuromuscular blockade received ventilatory support for one to three hours after operation. Respiratory failure was significantly more frequent in patients who received cyclosporine $(P<0.05)$.

\section{Key words}

ANTAGONISTS: neuromuscular relaxants, edrophonium, neostigmine;

IMMUNE RESPONSE: suppression, cyclosporine;

INTERACTIONS: antagonists, neuromuscular relaxants; KIDNEY: transplantation;

NEUROMUSCULAR RELAXANTS: atracurium, vecuronium.

From the Department of Anesthesiology, University of Florida College of Medicine, Box J-254, J. Hillis Miller Health

Center, Gainesville, FL 32610-0254, U.S.A.

Address correspondence to: Dr. A. Sidi.
En un an, quatre des 36 patients qui avaient reçu de l' atracurium et quatre des 29 autres qui avaient eu du vécuronium lors de leur transplantation rénale ont été affligés d'un bloc neuromusculaire prolongé ou d'un épisode de défaillance respiratoire. L'induction de l'anesthésie avec du thiopental, de isoflurane et du protoxyde d' azote précédait l' injection d' un bolus de 0,07 à $0,1 \mathrm{mg} \cdot \mathrm{kg}^{-1}$ de vécuronium ou de 0,3 à $0,5 \mathrm{mg} \cdot \mathrm{kg}^{-1}$ d'atracurium avant l' intubation de la trachée. L'êvaluation visuelle de la réponse neuromusculaire au train-de-quatre ondes ou la stimulation tétanique guidait l'énjection de doses additionnelles alors qu'on ajoutait du fentanyl au régime d'isoflurane et de protoxyde d'azote. Aprés l'induction, on injectait en plus de la méthylprednisolone, de la céfazoline et du mannitol (perfusé pendant $24 \mathrm{~h}$ suite à l'anastomose de l'artère rénale) soit de l'azathioprine $(n=57)$ soir de la cyclosporine $(n=8)$. A la fin de l'intervention, on contrait le bloc neuromusculaire résiduel (évalué avec le train-de-quatre ondes) avec 0,75 à $/ \mathrm{mg} \cdot \mathrm{kg}^{-1}$ avec 0,06 a $0,08 \mathrm{mg} \cdot \mathrm{kg}^{-1}$ de néostigmine. On dut supporter mécaniquement la ventilation des huit patients au bloc neuromusculaire persistant pour une période d' une à trois heures. En rétrospective, ces épisodes de défaillance respiratoire survenaient de préférence chez ceux qui avaient reçu de la cyclosporine $(P<0,05)$.

Atracurium undergoes extensive spontaneous degradation by Hofmann elimination and ester hydrolysis into products that are inactive at the neuromuscular junction. Because of this and because only about 5 to 20 per cent of vecuronium is eliminated in the urine, ${ }^{1,2}$ either vecuronium or atracurium is considered to be appropriate for use in patients with renal failure. In several studies of anephric patients treated with either vecuronium ${ }^{2-4}$ or atracurium, ${ }^{3,5-9}$ neither the pharmacokinetic nor the pharmacodynamic behaviour was affected and recurarization did not occur, even with four to eight times the recommended dose for tracheal intubation. ${ }^{2-6}$ We have noticed that some patients with renal failure who underwent renal transplantation suffered prolonged neuromuscular blockade, ventilatory failure, or both, postopera- 
tively. To determine the incidence and possible cause of these problems, the records of all patients who underwent renal transplantation during one year were examined.

\section{Methods}

The records of all patients who underwent kidney transplantation during 1986 were reviewed retrospectively. At the study institution all such operations were done semi-electively, and haemodialysis was performed within $24 \mathrm{hr}$ of operation so that preoperative serum potassium concentration was 3.5 to $5 \mathrm{mEq} \cdot \mathrm{L}^{-1}$. Premedication one hour before operation consisted of ranitidine hydrochloride, $150 \mathrm{mg}$, and Bicitra, $30 \mathrm{ml}$ orally, in addition to all other medications the patients were receiving on a regular basis.

Anaesthesia was induced with thiopentone, 3-5 $\mathrm{mg} \cdot \mathrm{kg}^{-1}$, and tracheal intubation was facilitated with fentanyl/isoflurane and $\mathrm{N}_{2} \mathrm{O}$ and $\mathrm{O}_{2}$ with or without muscle relaxants. The latter included a "priming" or full dose of atracurium or vecuronium, or succinylcholine. A baseline response to neuromuscular stimulation was recorded in patients who did not receive succinylcholine. Anaesthesia was maintained with isoflurane, expired concentration, $0.5-1$ per cent in 60 per cent $\mathrm{N}_{2} \mathrm{O}$ and 40 per cent $\mathrm{O}_{2}$. Arterial oxygen saturation $\left(\mathrm{SaO}_{2}\right)$, measured by pulse oximetry, was kept at 97-100 per cent and oesophageal temperature at $35-37^{\circ} \mathrm{C}$. Mechanical ventilation was administered at a rate to keep $\mathrm{PETCO}_{2}$ at 30 to $40 \mathrm{mmHg}$. Both the end-tidal concentration of isoflurane and $\mathrm{PETCO}_{2}$ were monitored by a mass spectrometer (Perkin-Elmer \# 1100) every three to five minutes.

After induction of anaesthesia, each patient received cefazolin sodium, $1 \mathrm{~g}$; methylprednisolone, $3 \mathrm{mg} \cdot \mathrm{kg}^{-1}$ in five per cent glucose solution; and mannitol, $25 \mathrm{~g}$ in 2.5 per cent solution; these drugs were continued for the first $24 \mathrm{hr}$ after operation. At the start of the renal artery anastomosis, methylprednisolone, $1 \mathrm{~g}$, and azathioprine, $5 \mathrm{mg} \cdot \mathrm{kg}^{-1} \mathrm{IV}$, were given. Cyclosponine, $5 \mathrm{mg} \cdot \mathrm{kg}^{-1} \mathrm{IV}$, was given instead of azathioprine to patients who had chronic leukopenia, or who were receiving allopurinol and were undergoing a second transplantation, or who were experiencing rejection of a previously transplanted kidney and were refractory to steroids.

Neuromuscular function was monitored by observing visually the force of contraction of the adductor pollicis muscle in response to train-of-four (TOF) stimulation. ${ }^{10}$ The ulnar nerve was stimulated supramaximally at the wrist or the elbow with surface cutaneous electrodes. After baseline response to nerve stimulation was assessed, either vecuronium, $0.07-0.1 \mathrm{mg} \cdot \mathrm{kg}^{-1}$ or atracurium, $0.3-0.5 \mathrm{mg} \cdot \mathrm{kg}^{-1}$ was injected as a single bolus. Neuromuscular blockade was maintained during operation with repeated boluses of the initial muscle relaxant, vecuronium, $0.01-0.03 \mathrm{mg} \cdot \mathrm{kg}^{-1}$ or atracurium, $0.1-0.2$ $\mathrm{mg} \cdot \mathrm{kg}^{-1}$. They were given whenever the force of the last stimulus of the TOF was judged to be $\geq$ two of four twitches and in relation to the surgical procedure. Neuromuscular blockade was evaluated (TOF and tetanus) every 15 min during the surgical procedure.

Toward the end of operation, when one to two responses to TOF stimulation were observed, neuromuscular blockade was reversed with atropine, $0.02 \mathrm{mg} \cdot \mathrm{kg}^{-1}$ and either edrophonium, $0.75-1.0 \mathrm{mg} \cdot \mathrm{kg}^{-1}$, or neostigmine, $0.06-0.08 \mathrm{mg} \cdot \mathrm{kg}^{-1}$. When clinically appropriate, the trachea was extubated and the patient was moved to the recovery room where neuromuscular activity was assessed by the usual clinical criteria, which included adequacy of respiration (rate, volume, and $\mathrm{SaO}_{2}$ maintained without respiratory effort), hand grip, and head lift. When ventilation was supported mechanically in the recovery room, monitoring consisted of pulse oximetry, $\mathrm{PETCO}_{2}$, repeated expiratory spirometry every $30 \mathrm{~min}$ and, if additional assessment of the adequacy of ventilation was needed, arterial blood gas analysis. Tracheas were extubated in the recovery room when forced vital capacity by spirometry was $>15 \mathrm{ml} \cdot \mathrm{kg}^{-1}$, inspiratory force measured on the ventilator manometer was $\leq-20$ $\mathrm{cm} \mathrm{H}_{2} \mathrm{O}, \mathrm{SaO}_{2}$ was $>97$ per cent, $\mathrm{PeTCO}_{2}$ was $<40$ $\mathrm{mmHg}$ with spontaneous ventilation, and TOF had returned to normal and the response to tetanus was sustained. All patients were treated with corticosteroids as part of the immunosuppressive protocol.

The occurrence of respiratory failure and prolonged blockade was compared in patients according to patient's characteristics, anaesthetics and anaesthetic-related agents used, and immunosuppressive agents by grouped non-paired $t$ test and by Fisher's exact probability test; $P$ $<0.05$ was considered significant. Values are reported as means \pm SEM.

\section{Results}

In 1986,65 patients with end-stage renal disease underwent kidney transplantation ( 51 received a cadaver kidney). The mean age of the patients was $39.8 \pm 1.9 \mathrm{yr}$ ( \pm SEM), and mean weight $70.1 \pm 2.1 \mathrm{~kg}$. Eight patients had previously undergone renal transplantation. All of them suffered hypertension but only 34 were treated with antihypertensive agents. Length of operation was $3.5 \pm$ $0.6 \mathrm{hr}$. Premedication consisted of diazepam, 5-10 mg, in 20 patients; phenergan, $25-50 \mathrm{mg}$, in four; and midazolam, $1-3 \mathrm{mg}$, in five. Isoflurane was used to supplement anaesthesia in 63, the maintenance dose ranging from $0.5-2$ per cent inspired (0.5-1 per cent end tidal) concentration. In two patients, $\mathrm{N}_{2} \mathrm{O}$ and a narcotic were used for anaesthetic maintenance.

Eight patients (12 per cent) suffered respiratory failure 
TABLE I Anaesthetic regimen for patients who underwent renal transplantation

\begin{tabular}{|c|c|c|c|c|}
\hline & \multicolumn{2}{|c|}{ With respiratory failure } & \multicolumn{2}{|c|}{ Without respiratory failure } \\
\hline & Mean $\pm S E M$ & $n$ & Mean $\pm S E M$ & $n$ \\
\hline \multicolumn{5}{|l|}{ Additional muscle relaxant $\left(\mathrm{mg} \cdot \mathrm{kg}^{-1}\right)$} \\
\hline - Succinylcholine & $1.42 \pm 0.33$ & 5 & $1.39 \pm 0.07$ & 25 \\
\hline - d-Tubocurarine & $0.07 \pm 0.01$ & 2 & $0.06 \pm 0.01$ & 8 \\
\hline \multicolumn{5}{|l|}{ Anaesthetic induction } \\
\hline $\begin{array}{l}\text { - Narcotic/fentanyl }\left(\mu \mathrm{g} \cdot \mathrm{kg}^{-1}\right) \\
\text { - Muscle relaxant }\left(\mathrm{mg} \cdot \mathrm{kg}^{-1}\right)\end{array}$ & $1.46 \pm 0.43$ & 6 & $2.78 \pm 0.36$ & 45 \\
\hline - Vecuronium & $0.12 \pm 0.03$ & 4 & $0.10 \pm 0.01$ & 27 \\
\hline - Atracurium & $0.45 \pm 0.07$ & 2 & $0.45 \pm 0.03$ & 28 \\
\hline \multicolumn{5}{|l|}{ Anaesthetic maintenance } \\
\hline $\begin{array}{l}\text { - Narcotic/fentanyl }\left(\mu \mathrm{g} \cdot \mathrm{kg}^{-1}\right) \\
\text { - Single dose relaxant }\left(\mathrm{mg} \cdot \mathrm{kg}^{-1}\right)\end{array}$ & $1.87 \pm 0.29$ & 3 & $2.11 \pm 0.27$ & 22 \\
\hline - Vecuronium & $0.01 \pm 0.00$ & 3 & $0.02 \pm 0.00$ & 27 \\
\hline - Atracurium & $0.18 \pm 0.03$ & 7 & $0.17 \pm 0.02$ & 28 \\
\hline \multicolumn{5}{|l|}{ - Total dose relaxant (mg $\left.\cdot \mathrm{kg}^{-1}\right)$} \\
\hline - Vencuronium & $0.02 \pm 0.01$ & 3 & $0.06 \pm 0.01$ & 27 \\
\hline - Atracurium & $0.88 \pm 0.15$ & 4 & $0.58 \pm 0.09$ & 28 \\
\hline
\end{tabular}

TABLE II Effects of reversal of neuromuscular blockade in patients who underwent kidney transplantation

\begin{tabular}{|c|c|c|c|c|}
\hline & \multicolumn{2}{|c|}{ With respiratory failure } & \multicolumn{2}{|c|}{ Without respiratory failure } \\
\hline & $M e a n \pm S E M$ & $n$ & $M e a n \pm S E M$ & $n$ \\
\hline \multicolumn{5}{|c|}{ Neuromuscular blockade reversal $\left(\mathrm{mg} \cdot \mathrm{kg}^{-1}\right)$} \\
\hline - Edrophonium & $0.94 \pm 0.00$ & 7 & $0.96 \pm 0.03$ & 41 \\
\hline - Neostigmine & 0.08 & 1 & $0.07 \pm 0.00$ & 14 \\
\hline \multicolumn{5}{|c|}{ Twitch response (no. visible twitches) } \\
\hline - Before reversal & $1.75 \pm 0.16$ & 8 & $2.77 \pm 0.60^{*}$ & 13 \\
\hline - After reversal & $3.75 \pm 0.16$ & 8 & $4.00 \pm 0.00$ & 57 \\
\hline \multicolumn{5}{|c|}{ Tidal volume after reversal } \\
\hline$-\mathrm{ml}$ & $231 \pm 4$ & 8 & - & 一 \\
\hline$-\mathrm{ml} \cdot \mathrm{kg}^{-1}$ & $3.03 \pm 0.49$ & 8 & - & - \\
\hline
\end{tabular}

$* P<0.05$ compared with that value for patients who had respiratory failure.

or muscle weakness, as indicated by either a failure to sustain contraction to a five-second tetanic stimulation ( $n$ $=3$ ) or by a low tidal volume (100 to $200 \mathrm{ml}$ ) during spontaneous ventilation $(n=7)$, which resulted in an $\mathrm{SaO}_{2}<90$ per cent $(n=8)$. Three of these patients required reintubation because $\mathrm{SaO}_{2}$ decreased within one to 15 min after extubation when the TOF had shown four twitches and contraction was sustained for five seconds after tetanic stimulation. In all patients who suffered respiratory failure, ventilatory support, with or without re-intubation, was required for one to three hours after operation (four to six hours total time after the last bolus of relaxant).

The ages and weights of the patients did not differ between those who did and did not suffer respiratory failure $(38.0 \pm 3.0$ and $39.8 \pm 1.9 \mathrm{yr}$ and $79.1 \pm 9.0$ and $70.1 \pm 2.1 \mathrm{~kg}$, respectively). From the comparison of patients with and without respiratory failure (Tables I-V), it occurred significantly more often in patients who received cyclosporine (five of 57 patients without respiratory failure compared with three of eight with respiratory failure; $P<0.05$ by Fisher's exact test). Also, the TOF value before reversal was significantly lower in patients who suffered respiratory failure than in patients who did not $(P<0.05)$ (Table II). However, the incidence of respiratory failure did not differ between atracurium- and vecuronium-treated patients (four of 36 compared with four of 29 , respectively). Incidence of hypertension and treatment of it before surgery did not differ between those who did and did not suffer respiratory failure - two of eight and 34 of 65 , respectively.

All three of the patients who required reintubation had received vecuronium. A fourth patient who received vecuronium was extubated in spite of clinical signs of 
TABLE III Anaesthetic ventilatory support and duration of operation for patients who underwent renal transplantation

\begin{tabular}{lll}
\hline & $\begin{array}{l}\text { With respiratory } \\
\text { failure }(n=8)\end{array}$ & $\begin{array}{l}\text { Without respiratory } \\
\text { failure }(n=57)\end{array}$ \\
\hline Time from last dose to end of operation $(\mathrm{hr})$ & & \\
- Narcotic & $2.81 \pm 0.31$ & $2.30 \pm 0.23$ \\
- Relaxant & $1.06 \pm 0.29$ & $1.18 \pm 0.10$ \\
Duration of operation (hr) & $3.44 \pm 0.29$ & $3.54 \pm 0.11$ \\
Duration of postoperative ventilatory support $(\mathrm{hr})$ & $1.69 \pm 0.27$ & - \\
\hline
\end{tabular}

Values are means \pm SEM.

TABLE IV Treatment with immunosuppressive agent in patients who did and did not have respiratory failure after renal transplantation.

\begin{tabular}{llcc}
\hline & $\begin{array}{l}\text { With respiratory } \\
\text { failure }\end{array}$ & $\begin{array}{l}\text { Without respiratory } \\
\text { failure }\end{array}$ & Total \\
\hline Azathioprine & 5 & 52 & 57 \\
Cyclosporine & 3 & $5^{*}$ & 8 \\
All & 8 & 57 & 65 \\
\hline
\end{tabular}

$* P<0.05$ vs corresponding incidence with respiratory failure.

muscle weakness and treated with other forms of ventilatory support. At the time of extubation, serum potassium was $2.1 \mathrm{mEq} \cdot \mathrm{L}^{-1}$. Preoperatively, serum potassium had been $3.7 \mathrm{mEq} \cdot \mathrm{L}^{-1}$, and hypokalaemia developed probably because the patient had been treated with insulin to control hyperglycaemia.

\section{Discussion}

In this retrospective study, respiratory failure developed in some anephric renal transplant recipients probably due to a prolonged neuromuscular blockade, and respiratory failure in this group occurred significantly more often in patients who received cyclosporine for immunosuppression. Using statistics in a retrospective clinical study has some problems, for example, similarity of samples and varying anesthetic techniques; however, we were analyzing a distinct and unique group of patients anaesthetized in a similar fashion, therefore the Fisher's exact test is appropriate.

A relationship between cyclosporine and enhanced neuromuscular blockade with vecuronium or atracurium has been reported in an experimental study of an anaesthetized cat preparation. "In that study, both cyclosporine and its solvent, Cremophor EL, potentiated the neuromuscular block produced by vecuronium and, to a lesser extent, that by atracurium. Another study demonstrated a similar interaction between vecuronium and Cremophor $\mathrm{EL}$ in a rat hemidiaphragm/phrenic nerve stimulation preparation. ${ }^{12}$ Intravenous cyclosporine may have contributed to the prolonged neuromuscular blockade in eight patients in this study; however, five of these eight did not
TABLE V Possible causes of respiratory failure

\begin{tabular}{|c|c|}
\hline Possible causes of respiratory failure & $\begin{array}{l}\text { Significance of } \\
\text { difference }\end{array}$ \\
\hline Age (yr) & NS \\
\hline Weight (kg) & NS \\
\hline Aminoglycosides $(n)$ & NS \\
\hline Antihypertensive drugs $(n)$ & NS \\
\hline Metabolic disorder - hypokalemia $(n)$ & NS \\
\hline $\mathrm{d}$-Tubocurarine $\left(\mathrm{mg} \cdot \mathrm{kg}^{-1}\right)$ & NS \\
\hline Succinylcholine $\left(\mathrm{mg} \cdot \mathrm{kg}^{-1}\right)$ & NS \\
\hline \multicolumn{2}{|l|}{ Fentanyl $\left(\mu g \cdot \mathrm{kg}^{-1}\right)$} \\
\hline - Induction & NS \\
\hline - Maintenance & NS \\
\hline Isoflurane (\% ET) & NS \\
\hline \multicolumn{2}{|l|}{ Relaxants (mg $\cdot \mathrm{kg}^{-1}$ ) } \\
\hline - Induction & NS \\
\hline - Maintenance & NS \\
\hline \multicolumn{2}{|l|}{ Time from last bolus (hr) } \\
\hline - Relaxant & NS \\
\hline - Narcotic & NS \\
\hline Atracurium $\left(\mathrm{mg} \cdot \mathrm{kg}^{-1}\right) ;(n)$ & NS \\
\hline Vecuronium (mg ' kg-1); (n) & NS \\
\hline Edrophonium $\left(\mathrm{mg} \cdot \mathrm{kg}^{-1}\right) ;(n)$ & NS \\
\hline \multicolumn{2}{|l|}{ Immunosuppressive drugs ( $n$ ) } \\
\hline - Azathioprine & NS \\
\hline - Cyclosporine & $P<0.05$ (Table IV) \\
\hline Train-of-four before reversal (TOF) & $P<0.05$ (Table II) \\
\hline
\end{tabular}

receive cyclosporine. Therefore, other potential causes for prolonged neuromuscular blockade in this patient population must also be carefully considered.

None of the eight patients had sepsis or post-transfusion pulmonary oedema. Possible causes of the prolonged neuromuscular blockade in all eight include liver disease, ${ }^{13}$ effect of accumulation of muscle relaxant, ${ }^{14,15}$ acid-base and electrolyte imbalances, ${ }^{16}$ or the effect of succinylcholine, ${ }^{17}$ narcotics, isoflurane, ${ }^{13.16,18,19}$ or other nonanaesthetic drugs such as aminoglycosides, ${ }^{20-22}$ corticosteroids, ${ }^{23}$ or azathioprine. ${ }^{24}$ All factors that could have caused or contributed to respiratory failure were compared by incidence of frequency or grouped value in patients who did or did not suffer respiratory failure (Table V). 
The main previous disease in all patients was hypertension, and its incidence and treatment was similar in all groups. None of the antihypertensive drugs used in this population has been tested with either atracurium or vecuronium or been proved to prolong neuromuscular block with these agents. Only in one patient of eight could an electrolyte abnormality (hypokalaemia) be demonstrated that could explain the prolonged relaxation. No direct relationship was demonstrated between respiratory failure and the use of azathioprine or steroids in these patients, but the use of aminoglycosides (one of eight patients) cannot be eliminated as a potential factor. The amount and timing of relaxants, narcotics, and isoflurane did not differ between the respiratory groups. Although neuromuscular blockade is potentiated by isoflurane, a significant residual effect of isoflurane one to three hours after administration of one per cent end tidal concentration is unlikely. Finally, excessive narcotic is an unlikely cause of respiratory insufficiency in our patients because they were all awake and breathing at a respiratory rate $>20$ breaths $\cdot \mathrm{min}^{-1}$.

The use of edrophonium for reversal (seven of the eight patients) could have been a factor since its effect may be shorter than that of neostigmine. ${ }^{16}$ Also, edrophonium and neostigmine are not equally effective against atracurium and vecuronium. ${ }^{25}$ However, when a large dose $\left(0.5-1 \mathrm{mg} \cdot \mathrm{kg}^{-1}\right)$ is used, sustained reversal of the blockade results, ${ }^{26}$ and its elimination is similar to that of neostigmine. ${ }^{27}$ Also the incidence of the use of edrophonium among patients who suffered respiratory failure was similar to that of patients who did not. Twitch height when the antagonist was given to our patients was significantly higher in those who suffered respiratory failure than in patients who did not (Table II), which might be more predictive of prolonged muscle relaxation.

In spite of the potential faults of a retrospective study, and the imprecision of visual monitoring, ${ }^{28,29}$ cyclosporine is implicated in prolonged neuromuscular blockade by our data. The safety profile of atracurium in recent studies in the United Kingdom and United States does not exclude a low incidence of respiratory depression. ${ }^{30.31}$ Therefore, the effect of cyclosporine on both atracurium and vecuronium should be tested experimentally and clinically.

\section{References}

1 Upton RA, Nguyen TL, Miller RD, Castagnoli $N$ $J r$. Renal and biliary elimination of vecuronium (Org NC45) and pancuronium in rats. Anesth Analg 1982; 61: 313-6.

2 Bencini AF, Scaf AHJ, Sohn YJ et al. Disposition and urinary excretion of vecuronium bromide in anesthetized patients with normal renal function or renal failure. Anesth Analg 1986; 65: 245-51.
3 Hunter JM, Jones RS, Utting JE. Comparison of vecuronium, atracurium and tubocurarine in normal patients and in patients with no renal function. Br J Anaesth 1984; 56 : 941-50.

4 Fahey MR, Morris RB, Miller RD, Nguyen TL, Upron $R A$. Pharmacokinetics of Org NC45 (Norcuron) in patients with and without renal failure. Br J Anaesth 1981; 53: 1049-53.

5 Fahey MR, Rupp SM, Fisher DM et al. The pharmacokinetics and pharmacodynamics of atracurium in patients with and without renal failure. Anesthesiology 1984; 61: 699-702.

6 Hunter $J M$, Jones RS, Utting $J E$. Use of atracurium in patients with no renal function. Br J Anaesth 1982; 54 1251-8.

7 Mongin-Long D, Chabrol B, Baude $C$ et al. Atracurium in patients with renal failure: clinical trial of a new neuromuscular blocker. Br J Anaesth 1986; 58: 44S-8S.

8 Russo R, Ravagnan $R$, Buzzetti $V$, Favini $P$. Atracurium in patients with chronic renal failure. $\mathrm{Br} J$ Anaesth 1986; 58: 63S.

9 Miller RD. Pharmacokinetics of atracurium and other nondepolarizing ncuromuscular blocking agents in normal patients and those with renal or hepatic dysfunction. $\mathrm{Br} \mathrm{J}$ Anaesth 1986; 58: 11S-3S.

10 Ali $H H$, Utting JE, Gray $C$. Stimulus frequency in the detection of neuromuscular block in humans. $\mathrm{Br} \mathrm{J}$ Anaesth 1970; 42: 967-78.

11 Gramstad L, Gjerlow JA, Hysing ES, Rugstad E. Interaction of cyclosporin and its solvent, cremophor, with atracurium and vecuronium: studics in the cat. $\mathrm{Br} J$ Anacsth 1986; 58: 1149-55.

12 Fragen RJ, Booij LHDJ, van der Pol F, Robertson EN, Crul JF. Interactions of disopropyl phenol (ICl 35 868 ) with suxamethonium, vecuronium and pancuronium in vitro. Br J Anaesth 1983; 55: 433-6.

13 Bencini A, Scaf AHJ, Sohn YJ, Kersten U, Agoston $S$. Clinical pharmacokinetics of vecuronium, clinical experiences with Norcuron (Org NC45, vecuronium bromide). In: Agoston S, Bowman WC, Miller RD, Viby-Mogensen J (Eds.). Current Clinical Practice, vol 11. Amsterdam, Excerpta Medica, 1983; 115.

14 Bevan DR, Donati F, Gyasi H, Williams A. Vecuronium in renal failure. Can Anaesth Soc J 1984; 31: 491-5.

15 Starsnic MA, Goldberg ME, Ritter DE, Marr AT. Sosis M, Larijani $G E$. Does vecuronium accumulate in the renal transplant patient? Can J Anaesth 1989; 36: 35-9.

16. Miller RD. Savarese JJ. Pharmacology of muscle relaxants and their antagonists. In: Miller RD (Ed.). Anesthesia, 2nd ed. Philadelphia, JB Lippincott, 1986; 889-943.

17 Stirt JA, Katz RL, Murray AL, Schehland DL, Lee $C$. Modification of atracurium blockade by halothane and by suxamethonium: a review of clinical experience. $\mathrm{Br}$ 
J Anacsth 1983; 55: 71S-5S.

18 Rupp SM, Miller RD, Gencarelli PJ. Vecuroniuminduced neuromuscular blockade during enflurane, isoflurane, and halothane anesthesia in humans. Ancsthesiology 1984; 60: 102-5.

19 Lynam DP, Cronnelly R, Arden J, Castagnoli K, Canfell $C$, Miller $R D$. The pharmacodynamics and pharmacokinetics of vecuronium in patients with and without renal failure. Anesthcsiology 1986; 65: A296.

20 Kronenfeld MA, Thomas SJ, Turndorf $H$. Recurrence of neuromuscular blockade after reversal of vecuronium in a patient receiving polymyxin/amikacin sternal irrigation. Anesthesiology 1986; 65: 93-4.

21 Shanks AB, Long T, Aitkenhead AR. Prolonged neuromuscular blockade following vecuronium: a casc report. $\mathrm{Br}$ J Anaesth 1985; 57: 807-10.

22 Bizzarri-Schmid MD, Desai SP. Prolonged neuromuscular blockade with atracurium. Can Anacsth Soc J 1986; 33: 209-12.

23 Viby-Mogensen $J$. Interaction of other drugs with muscle relaxants. In: Katz RL (Ed.). Muscle Relaxants: Basic and Clinical Aspects. Orlando, Grune and Stratton, 1985.

24 Dretchen KL, Morgenroth VH, Standaert FG, Walts $L F$. Azathioprine: effects on neuromuscular transmission. Anesthesiology 1976; 45: 604-9.
25 Smith $C E$, Donati $F$, Bevan DR. Dose-response relationships for edrophonium and neostigmine as antagonists of atracurium and vecuronium ncuromuscular blockade. Anesthesiology 1989; 71: 37-43.

26 Kopman AF. Edrophonium antagonism of pancuroniuminduced neuromuscular blockade in man. Ancsthesiology 1979; 51: 139-142.

27 Morris RB, Cronnelly R, Miller RD. Stanski DR, Fahey $M R$. Pharmacokinetics of edrophonium and neostigmine when antagonizing d-tubocurarine neuromuscular blockade in man. Anesthcsiology 1981; 54: 399-402.

28 Viby-Mogensen J, Jensen NH, Engbaek J, Ording $H$, Skovgaard LT, Chraemmer-Jorgensen B. Tactile and visual evaluation of the response to train-of-four nerve stimulation. Anesthesiology 1985; 63: 440-3.

29 Miller RD. Are studies of neuromuscular blocking drugs and their antagonists unnecessarily confusing? Anesthesiology 1986; 65: 569-71.

30 Jick H, Andrews EB, Tilson HH et al. Atracurium - a post-marketing surveillance study: methods and U.S experience. Br J Anaesth 1989; 62: 590-5.

31 Lawson DH, Paice GM, Glavin RJ et al. Atracurium - a post-marketing surveillance study: U.K. study and discussion. Br J Anaesth 1989; 62: 596-600. 